\title{
Serological Features of Children Vertically Infected With Hepatitis B Virus: A Study in Amir Al-Momenin Ali Hospital of Zabol
}

\author{
Iraj Shahramian ${ }^{1}$, Abdolvahab Moradi $^{\circledR}{ }^{\circledR}$, Pouya Ostadrahimi' $^{1}$, Hadi Mirzaei ${ }^{\circledR}$, Mahboobeh $^{1}$ \\ Sheikh', Ali Khosravi Bonjar ${ }^{1}$, Samira Abdollahi ${ }^{3}$, Ali Bazi ${ }^{1 *}$ \\ ${ }^{1}$ Pediatric Gastroenterology and Hepatology Research Center, Zabol University of Medical Sciences, Zabol, Iran \\ ${ }^{2}$ Infectious Diseases Research Centre, Golestan University of Medical Sciences, Gorgan, Iran \\ ${ }^{3}$ Student Research Committee, Zabol University of Medical Sciences, Zabol, Iran
}

\section{*Correspondence to}

Ali Bazi,

Email: m.baziali@gmail.com

Received December 26, 2020 Accepted February 7, 2021 Published online March 31, 2021

\begin{abstract}
Introduction: Hepatitis B is a common viral infection worldwide and the main cause of chronic hepatitis, cirrhosis and liver cell carcinoma. hepatitis B e-antigen $(\mathrm{HBeAg})$ is one of the markers indicating chronic hepatitis B infection. In this cross-sectional study, we investigate serological markers and $\mathrm{HBeAg}$ positivity in in children with maternally transmitted hepatitis B virus (HBV). Materials and Methods: Overall, 26 children with congenital HBV referred to Amir AlMo'menin Ali hospital in Zabol in 2019 and 2020 were enrolled. After gathering demographic characteristics, blood samples were taken from the patients. Serological tests were performed by routine ELISA tests. Data were analyzed using SPSS software version 22.

Results: Twenty-six children were included in the study; 18 of them $(69.2 \%)$ were males. The mean age of the participants was $13.98 \pm 11$ years (minimum of 1 and maximum of 18 years old). The mean age of mothers was $40.45 \pm 10$ years (minimum of 27 and maximum of 63 years old). Four $(15.4 \%)$ of the children were HBeAg positive, and $18(69.2 \%)$ were $\mathrm{HBeAb}$ positive with no significant differences between genders $(P>0.05)$. HBeAg positivity was not associated with the birth rank $(P=0.71)$ or HBV vaccination $(P=0.17)$. Liver enzymes, serum albumin and children's age and duration of maternal infection were not significantly different between $\mathrm{HBeAg}$ positive and $\mathrm{HBeAg}$ negative groups $(P>0.05)$. Mean serum alanine transaminase (ALT) was significantly higher in $\mathrm{HBeAb}$ positive than $\mathrm{HBeAb}$ negative children $(P=0.018)$, and $\mathrm{HBeAb}$ positivity was significantly associated with HBV vaccination history $(P=0.02)$. Other liver enzymes as well as age of mother and child and the duration of maternal infection were not significantly different between the two groups $(P>0.99)$.

Conclusion: The prevalence of chronic HBV infection based on HBeAg positivity was relatively high in children vertically infected with the virus. HBeAb seroconversion seems to be associated with $\mathrm{HBV}$ vaccination.

Keywords: Hepatitis B virus, Vertical infection, Aminotransferases, Vaccination
\end{abstract}

about $3 \%$ of them are chronic carriers, the lowest of which has been reported in Fars province $(2.7 \%)$ and the highest in Sistan and Baluchestan (5\%). ${ }^{6}$

Mother-to-child (vertical) transmission (MTCT) is one of the most important ways through which HBV is transmitted. This method of transmission may occur through the placenta, during labor, or shortly thereafter. ${ }^{7}$ More than 50\% of Iranian carriers received the infection from their mothers, which is one of the most likely routes of $\mathrm{HBV}$ transmission in our

(C) 2021 The Author(s); Published by Zabol University of Medical Sciences. This is an open-access article distributed under the terms of the Creative Commons Attribution License (http://creativecommons.org/licenses/by/4.0), which permits unrestricted use, distribution, and reproduction in any medium, provided the original work is properly cited. 
country. ${ }^{5}$ Maternally infected children are 25 percent more likely than others to develop cirrhotic liver cancer. ${ }^{8}$ Among most important predictors of MTCT are HBV DNA status, as well as serological status for hepatitis $B$ e-antigen ( $\mathrm{HBeAg}$ ) and $\mathrm{HBeAb}{ }^{9}$ Children who acquire $\mathrm{HBV}$ prenatally have a high chance for developing chronic and persistent disease. In these children, seroconversion of $\mathrm{HBeAg}$ to $\mathrm{HBeAb}$ is an important marker indicating the inactivation of virus replication; in case of this phenomenon is not seen, patients will need a continuation of antiviral therapy. ${ }^{10}$ The rate of elimination of $\mathrm{HBeAg}$, with or without $\mathrm{HBeAb}$ positivity, is seen in a relatively low ratio of patients. ${ }^{11}$

Due to the high prevalence of hepatitis B in Sistan and Baluchestan province of Iran, and the fact that HBV clinical course is largely unknown in children with maternally transmitted $\mathrm{HBV}$, we here decided to evaluate the status of $\mathrm{HBeAg}$ and $\mathrm{HBeAb}$ in these children before the age of 18 years old.

\section{Patients and Methods}

This cross-sectional study was performed on 26 children ( $<18$ years old) born with congenital HBV infection (HBs Ag positivity at birth) in the Amir-Al-Momenin hospital of Zabol city. After obtaining an informed consent from parents and completing a questionnaire for demographic characteristics, blood samples were taken from children.

Laboratory tests including aspartate aminotransferase (AST), alanine transaminase (ALT), $\mathrm{HBeAg}, \mathrm{HBeAb}, \mathrm{HBsAg}$, alkaline phosphatase (ALP), albumin, bilirubin total, bilirubin direct, and total protein were determined for all children using specific ELISA kits. Data was analyzed using SPSS software version 22 using the chi-square test and independent sample student $t$ test at the significance level of $P<0.05$.

\section{Results}

Twenty-six children were included in this study;18 of them (69.2\%) were males. All these children had positive HBsAg test at birth. The mean age of the children was $10.98 \pm 6.35$ years. The youngest and oldest were 1 and 18 years old, respectively. The mean age of the mothers was $40.45 \pm 10$ years (the range of 27 to 63 years). Half of the children (52\%) were the second child of the family. Table 1 shows laboratory parameters in the studied children.

Table 2 shows that $4(15.4 \%)$ of the children were $\mathrm{HBeAg}$ positive. The frequency of $\mathrm{HBeAb}$ positivity was $18(69.2 \%)$.

Overall, $20 \%$ of boys and $0 \%$ of girls were $\mathrm{HBeAg}$ positive; however, the difference between the two sexes was not statistically significant $(P>0.05)$ (Table 3$)$. $\mathrm{HBeAg}$ positivity was not associated with the birth rank or HBV vaccination $(P=0.155)$. Also, liver enzymes, serum albumin, patient's age, and duration of maternal infection were not significantly different between the two groups $(P>0.05)$.

Table 4 shows that $\mathrm{HBeAb}$ positivity was not significantly associated with a history of labor bleeding, gender, or birth rank. However, the frequency of $\mathrm{HBeAg}$ positivity was significantly higher in children without a history of $\mathrm{HBV}$ vaccination $(P=0.001)$. Furthermore, the mean serum ALT was significantly higher in $\mathrm{HBeAb}$ positive than negative children $(P=0.018)$. Other liver enzymes as well as patients' and mother ages, and duration of maternal infection were not significantly different between the two groups.

\section{Discussion}

In the present study, out of 26 children aged $<18$ years old born to $\mathrm{HBs} \mathrm{Ag}$ positive mothers, 4 (15.4\%) were $\mathrm{HBeAg}$ positive, and $18(69.2 \%)$ were $\mathrm{HBeAb}$ positive. All the children were HBsAg positive at birth. HBeAg positivity was not associated with the birth rank or $\mathrm{HBV}$ vaccination $(P=0.155)$, but the mean of serum total bilirubin was significantly lower in $\mathrm{HBeAg}$ positive patients than in HBeAg negative ones ( 0.65 vs $1.07, P=0.019)$. However, liver enzymes, serum albumin, patient age, and duration of maternal infection were not significantly different between the two groups $(P>0.05)$.

In a study in Taiwan, the prevalence of the children

Table 2. HBeAg and HBeAb Status in the Studied Children

\begin{tabular}{ccccc}
\hline \multirow{2}{*}{ Serological Variables } & \multicolumn{2}{c}{ HBeAb } & \multirow{2}{*}{$\boldsymbol{P}$} \\
\cline { 3 - 4 } & & Positive & Negative & \\
\hline \multirow{2}{*}{$\mathrm{HBeAg}$} & Positive & $1(5)$ & $3(37.5)$ & \multirow{2}{*}{0.072} \\
& Negative & $17(95)$ & $5(62.5)$ & \\
\hline
\end{tabular}

Table 1. Laboratory Parameters in the Studied Children

\begin{tabular}{lccc}
\hline Variables & Mean (SD) & Median & Minimum \\
\hline AST (IU/L) & $15.57(6.81)$ & 14 & 9 \\
ALT (IU/L) & $15.11(6.26)$ & 14.5 & 8 \\
ALP (IU/L) & $374.11(209.14)$ & 353.5 & 30 \\
Direct Bilirubin (mg/dL) & $0.23(0.07)$ & 0.25 & 720 \\
Total Bilirubin (mg/dL) & $1.05(0.52)$ & 0.90 & 0.10 \\
Albumin (mg/dL) & $5.23(1.33)$ & 4.95 & 0.30 \\
Total protein (mg/dL) & $8.15(0.72)$ & 8.15 & 3.29 \\
\hline
\end{tabular}


Table 3. HBeAg Status and its Association with Laboratory and Clinical Parameters

\begin{tabular}{|c|c|c|c|c|}
\hline \multirow{2}{*}{ Variables } & & \multicolumn{2}{|c|}{ HBeAg } & \multirow[b]{2}{*}{$\boldsymbol{P}$} \\
\hline & & $\begin{array}{c}\text { Positive } \\
(n=4)\end{array}$ & $\begin{array}{c}\text { Negative } \\
(n=22)\end{array}$ & \\
\hline \multicolumn{2}{|l|}{ Child's age $(y)$} & $8.5 \pm 7.32$ & $11.43 \pm 6.24$ & 0.40 \\
\hline \multicolumn{2}{|l|}{ Mother's age $(y)$} & $38 \pm 11.69$ & $41 \pm 9.89$ & 0.6 \\
\hline \multicolumn{2}{|l|}{ AST (IU/L) } & $18.75 \pm 5.67$ & $15 \pm 6.96$ & 0.06 \\
\hline \multicolumn{2}{|l|}{ ALT (IU/L) } & $14 \pm 3.36$ & $15.13 \pm 6.7$ & 0.9 \\
\hline \multicolumn{2}{|l|}{ ALP (IU/I) } & $375.5 \pm 198.38$ & $373.86 \pm 215.65$ & 0.98 \\
\hline \multicolumn{2}{|l|}{ Direct bilirubin (mg/dL) } & $0.25 \pm 0.05$ & $0.23 \pm 0.07$ & 0.81 \\
\hline \multicolumn{2}{|l|}{ Total bilirubin (mg/dL) } & $0.65 \pm 0.25$ & $1.13 \pm 0.52$ & 0.091 \\
\hline \multicolumn{2}{|l|}{ Albumin (mg/dL) } & $4.57 \pm 0.63$ & $5.35 \pm 1.40$ & 0.29 \\
\hline \multicolumn{2}{|l|}{ Total protein (mg/dL) } & $7.77 \pm 0.57$ & $8.21 \pm 0.73$ & 0.26 \\
\hline \multirow{2}{*}{ HBV vaccination } & Yes & $2(50)$ & $15(68.1)$ & \multirow{2}{*}{$0.17^{*}$} \\
\hline & No & $2(50)$ & $7(31.9)$ & \\
\hline \multirow{3}{*}{ Birth rank } & $1^{\text {st }}$ & $2(50)$ & $6(27.2)$ & \multirow{3}{*}{0.71} \\
\hline & $2^{\text {nd }}$ & $2(50)$ & $14(63.6)$ & \\
\hline & $4^{\text {th }}$ & $0(0)$ & $2(9.2)$ & \\
\hline
\end{tabular}

Data are expressed as mean \pm SD or No. $(\%)$.

* Fisher's exact test

Table 4. HBeAb Status and its Association With Laboratory and Clinical Parameters

\begin{tabular}{|c|c|c|c|c|}
\hline \multirow{2}{*}{ Variables } & & \multicolumn{2}{|c|}{ HBeAb } & \multirow[b]{2}{*}{$\boldsymbol{P}$} \\
\hline & & $\begin{array}{c}\text { Positive } \\
(n=18)\end{array}$ & $\begin{array}{c}\text { Negative } \\
(n=8)\end{array}$ & \\
\hline \multicolumn{2}{|l|}{ Child's age $(y)$} & $11.19 \pm 5.74$ & $10.5 \pm 7.98$ & 0.53 \\
\hline \multicolumn{2}{|l|}{ Mother's age (y) } & $41.66 \pm 10.07$ & $37.85 \pm 10.1$ & 0.53 \\
\hline \multicolumn{2}{|l|}{ AST (IU/L) } & $15.55 \pm 7.64$ & $15.65 \pm 4.89$ & 0.98 \\
\hline \multicolumn{2}{|l|}{ ALT (IU/L) } & $17 \pm 6.42$ & $10.87 \pm 3.22$ & 0.018 \\
\hline \multicolumn{2}{|l|}{ ALP (IU/L) } & $343.77 \pm 217.30$ & $435.62 \pm 187.86$ & 0.46 \\
\hline \multicolumn{2}{|l|}{ Direct bilirubin (mg/dL) } & $0.23 \pm 0.08$ & $0.23 \pm 0.05$ & 0.87 \\
\hline \multicolumn{2}{|l|}{ Total bilirubin (mg/dL) } & $0.92 \pm 0.43$ & $1.35 \pm 0.61$ & 0.08 \\
\hline \multicolumn{2}{|l|}{ Albumin (mg/dL) } & $5.52 \pm 1.25$ & $4.57 \pm 1.35$ & 0.11 \\
\hline \multicolumn{2}{|l|}{ Total protein (mg/dL) } & $8.19 \pm 0.59$ & $8.05 \pm 0.99$ & 0.56 \\
\hline \multirow{2}{*}{ HBV vaccination } & Yes & $12(66.6)$ & $5(62.5)$ & \multirow{2}{*}{$0.02 *$} \\
\hline & No & $6(33.4)$ & $3(37.5)$ & \\
\hline \multirow{3}{*}{ Birth rank } & $1^{\text {st }}$ & $5(27.7)$ & $3(37.5)$ & \multirow{3}{*}{0.74} \\
\hline & $2^{\text {nd }}$ & $11(61.1)$ & $5(62.5)$ & \\
\hline & $4^{\text {th }}$ & $2(11.2)$ & $0(0)$ & \\
\hline
\end{tabular}

* Fischer exact test.

Data are expressed as mean \pm SD or No. (\%).

carrying HBsAg, who born to HBsAg-positive mothers, was reported to be $2.4 \% .{ }^{12}$ In two reports in China, these rates were reported as $7.2 \%$ and $13.7 \% .^{13,14}$ Another study by Zhu in China found that $14.7 \%$ of these children carried HBsAg. ${ }^{15}$ These evidence shows that vertical transmission of HBV infection is a serious health concern among societies, and those infected with the virus via this route must be under close clinical surveillance. In the present study, we focused on the chronicity of HBV infection in children who acquired the virus from their mothers and were $\mathrm{HBs} \mathrm{Ag}$ positive at birth.

In a study in Senegal, of 10 infants who born with a positive $\mathrm{HBs} \mathrm{Ag}$ status, 5 showed either anti-HBs, $\mathrm{HBc}$, or $\mathrm{HBe}$ antibodies after 6 months. ${ }^{16}$ In another study in Japan on children with MTCT HBV infection, the seroconversion of $\mathrm{HBeAg}$ at the ages of 3 and 15 years was shown to be $26 \%$ and $42 \%$, respectively. ${ }^{17}$ The recent study indicates a higher rate of seroconversion with aging of children. Consistent with this, we here observed the mean ages of $8.5 \pm 7.32$ and $11.43 \pm 6.24$ in $\mathrm{HBeAg}$ positive 
and negative patients, respectively. Although the age difference was not statistically significant, which may be due to the low number $(n=4)$ of HBeAg positive cases, this indicates that there is a tendency toward $\mathrm{HBeAg}$ seroconversion with age.

Nevertheless, the rate of $\mathrm{HBeAg}$ seroconversion to $\mathrm{HBeAb}$ seems to be under the influence of multiple factors. This seems to be lower in children infected with HBV genotype $C .{ }^{17}$ In one study; however, genotype B was more commonly associated with both $\mathrm{HBeAg}$ and $\mathrm{HBeAb}$ positivity in children. ${ }^{18}$ Nonetheless, genotype C was still an independent risk factor for delayed $\mathrm{HBeAg}$ seroconversion. ${ }^{18}$ Despite the use of immunoprophylaxis, infants who became chronically infected with HBV may be infected in the womb, or the mother may have a high load of the virus, or the baby may have mutated viruses. Vaccine-escape virus mutants ${ }^{19,20}$ and $\mathrm{HBeAg}$ positivity in mothers ${ }^{21}$ were also found to be associated with chronic $\mathrm{HBV}$ infections in descendants. In fact, it has been noted that passing through an immune clearance phase and the appearance of HBeAbs can be delayed by core and pre-core mutations in $\mathrm{HBV}$ genome. ${ }^{22,23} \mathrm{HBV}$ viruses transmitted within a family have shown a higher rate of core and pre-core mutations at HBeAg clearance phase, probably due to interactions of the same virus strain with immune systems of multiple hosts. ${ }^{24}$ We here did not find any significant association between $\mathrm{HBeAg}$ positivity and parameters such gender, birth rank, or a history of HBV vaccination.

According to our study, $\mathrm{HBeAb}$ positivity was significantly higher in children with a history of HBV vaccination. Vaccination is a standard health care procedure for infants born from HBV infected mothers. ${ }^{25}$ Passive and active immunization of infants born to HBsAgpositive mothers is the most important and effective way to prevent perinatal transmission of HBV infection. . $^{19,20,26}$ The number of carriers among descendants is a good candidate to evaluate the effectiveness of the vaccination program. Studies in Taiwan and Hong Kong showed that the effect of the vaccine alone was significantly more pronounced, especially when the mother is $\mathrm{HBeAg}$ positive. ${ }^{27,28}$ We here reported that a history of vaccination may help to achieve immunity by promoting $\mathrm{HBeAb}$ production.

In the present study, $\mathrm{HBeAg}$ positive children here also had higher AST than HBeAg negative ones (18.75 \pm 5.6 vs $15 \pm 6.9$ ); however, this was statistically insignificant. On the other hand, ALT showed no significant difference between the two groups. An elevated ALT in these patients was better predicted by $\mathrm{HBeAg}$ status as patients with a positive $\mathrm{HBeAg}$ test are more likely to have abnormal ALT. ${ }^{29}$ Regarding HBeAb status, we noticed a significantly higher ALT level in those with a positive anti-HBeAg test $(17 \pm 3.22$ vs $10.87 \pm 3.22, P=0.01)$. This suggests that $\mathrm{HBeAb}$ seroconversion may not accurately predict the clinical condition at immune clearance phase, and the fact that HBV carriers may still suffer from some degrees of hepatic injury under the influence of other parameters. ${ }^{29}$ In previous studies, it was shown that 29 to $65 \%$ of $\mathrm{HBeAb}$ positive carriers still had variable degrees of HBV DNA..$^{29,30}$ Genotype D of HBV, especially strains with core and precore mutations, can independently predict elevated ALT in $\mathrm{HBeAb}$ positive patients. ${ }^{29}$ Patients with anti-HBeAb in their serum can still show degrees of hepatic injuries such as inflammation and necrosis. ${ }^{30}$

Some parameters regarding mothers' status of $\mathrm{HBV}$ infection (e.g., HBV DNA level, HBeAb titer, HBV DNA mutations) were not studied before and during pregnancy. Also, it is better to check HBV DNA mutations, virus strains, and histological parameters in vertically infected children with chronic infection to be able to better predict their clinical course.

\section{Conclusion}

Chronic HBV infection in vertically infected children was relatively high. Various parameters (either mother or child related) may influence $\mathrm{HBeAg}$ seroconversion in these children. Although there were no significant differences between the children regarding clinical course of the disease, it is advisable to monitor these children with chronic infection for possible hepatic injuries.

\section{Authors' contributions:}

IS: Concept, supervision, critically revising the manuscript; AM: concept, design; PO, MS, HM, and AKB: data collection; AB: Drafting the manuscript, statistical analysis.

\section{Ethical Approval}

The study was approved by the ethics committee of Zabol University of Medical Sciences (IR.ZBMU.REC.1398.197).

\section{Competing Interests}

The authors have no conflict of interest to declare.

\section{Funding}

This was a part of a thesis for acquiring specialization degree in pediatrics, funded by Zabol University of Medical Sciences.

\section{References}

1. Merat S. Hepatitis B in Iran. Arch Iran Med. 2000;3(4):192201.

2. Maynard JE. Hepatitis B: global importance and need for control. Vaccine. 1990;8 Suppl:S18-20. doi:10.1016/0264410x(90)90209-5

3. Gust ID. Epidemiology of hepatitis B infection in the Western Pacific and South East Asia. Gut. 1996;38(Suppl 2):S18-23. doi:10.1136/gut.38.suppl_2.s18

4. World Health Organization (WHO). Hepatitis B. https:// www.who.int/news-room/fact-sheets/detail/hepatitis-b.

5. Merat S, Rezvan $H$, Nouraie $M$, et al. The prevalence of hepatitis B surface antigen and anti-hepatitis B core antibody in Iran: a population-based study. Arch Iran Med. 2009;12(3):225-231. 
6. Kao JH, Chen PJ, Lai MY, Chen DS. Hepatitis B genotypes correlate with clinical outcomes in patients with chronic hepatitis B. Gastroenterology. 2000;118(3):554-559. doi:10.1016/s0016-5085(00)70261-7

7. Synder J, Pickering L. Viral hepatitis. In: Kliegman RM, Jenson HB, eds. Nelson Textbook Pediatrics. 16th ed. Philadelphia: WB Saunders; 2000:768-773.

8. Avery GB, Fletcher MA, MacDonald MG. Neonatology: Pathophysiology and Management of the Newborn. Lippincott; 1987 .

9. Bleich LM, Swenson ES. Prevention of neonatal hepatitis B virus transmission. J Clin Gastroenterol. 2014;48(9):765772. doi: $10.1097 / \mathrm{mcg} .0000000000000115$

10. Jara P, Bruguera M. [Hepatitis B in pregnant women and children]. Enferm Infecc Microbiol Clin. 2008;26 Suppl 7:66-70. doi:10.1016/s0213-005x(08)76521-2

11. Karayiannis P. Hepatitis B virus: old, new and future approaches to antiviral treatment. J Antimicrob Chemother. 2003;51(4):761-785. doi:10.1093/jac/dkg163

12. Tang JR, Hsu HY, Lin HH, Ni YH, Chang MH. Hepatitis B surface antigenemia at birth: a long-term follow-up study. J Pediatr. 1998;133(3):374-377. doi:10.1016/s00223476(98)70272-0

13. Chernesky MA, Blajchman MA, Castriciano S, Basbaum J, Spiak C, Mahony JB. Analysis of a pregnancy-screening and neonatal-immunization program for hepatitis $\mathrm{B}$ in Hamilton, Ontario, Canada, 1977-1988. Obstet Gynecol Surv. 1992;47(5):301-302.

14. Yu XL, Chen $\mathrm{CH}$, Zhong M. [Reasons of failure in blocking mother-infant transmission of HBV by using vaccine and related strategies]. Zhonghua Hu Li Za Zhi. 1997;32(2):6971.

15. Zhu Q, Lu Q, Gu X, Xu H, Duan S. A preliminary study on interruption of $\mathrm{HBV}$ transmission in uterus. Chin Med J (Engl). 1997;110(2):145-147.

16. Roingeard P, Diouf A, Sankale JL, et al. Perinatal transmission of hepatitis B virus in Senegal, west Africa. Viral Immunol. 1993;6(1):65-73. doi:10.1089/ vim.1993.6.65

17. Takano T, Tajiri H, Hosono S, et al. Natural history of chronic hepatitis B virus infection in children in Japan: a comparison of mother-to-child transmission with horizontal transmission. J Gastroenterol. 2017;52(9):10411050. doi:10.1007/s00535-017-1315-4

18. Ni YH, Chang MH, Wang KJ, et al. Clinical relevance of hepatitis B virus genotype in children with chronic infection and hepatocellular carcinoma. Gastroenterology. 2004;127(6):1733-1738. doi:10.1053/j.gastro.2004.09.048
19. Freij BJ, Fletcher MA, MacDonald MG. Neonatology, Pathophysiology and Management of the Newborn. 5th ed. Philadelphia: Lippincott Williams \& Wilkins; 1999.

20. Mahoney FJ. Update on diagnosis, management, and prevention of hepatitis B virus infection. Clin Microbiol Rev. 1999;12(2):351-366. doi:10.1128/cmr.12.2.351

21. Bahn A, Hilbert K, Martiné U, Westedt J, von Weizsäcker F, Wirth S. Selection of a precore mutant after vertical transmission of different hepatitis B virus variants is correlated with fulminant hepatitis in infants. J Med Virol. 1995;47(4):336-341. doi:10.1002/jmv.1890470408

22. Fattovich G, McIntyre G, Thursz M, et al. Hepatitis B virus precore/core variation and interferon therapy. Hepatology. 1995;22(5):1355-1362.

23. Kidd-Ljunggren $K$. Variability in hepatitis $B$ virus DNA: phylogenetic, epidemiological and clinical implications. Scand J Infect Dis. 1996;28(2):111-116. doi:10.3109/00365549609049059

24. Sede M, Lopez-Ledesma M, Frider B, et al. Hepatitis B virus depicts a high degree of conservation during the immunetolerant phase in familiarly transmitted chronic hepatitis $\mathrm{B}$ infection: deep-sequencing and phylogenetic analysis. J Viral Hepat. 2014;21(9):650-661. doi:10.1111/jvh.12196

25. Sasagawa Y, Yamada H, Morizane M, et al. Hepatitis B virus infection: prevention of mother-to-child transmission and exacerbation during pregnancy. J Infect Chemother. 2019;25(8):621-625. doi:10.1016/j.jiac.2019.03.014

26. Stanton KB, Geme JS, Schor N, eds. Nelson's Textbook of Pediatrics. 20th ed. Springer; 2017.

27. Beasley RP, Hwang LY, Lee GC, et al. Prevention of perinatally transmitted hepatitis $\mathrm{B}$ virus infections with hepatitis B immune globulin and hepatitis B vaccine. Lancet. 1983;2(8359):1099-1102. doi:10.1016/s01406736(83)90624-4

28. Tsebe KV, Burnett RJ, Hlungwani NP, Sibara MM, Venter PA, Mphahlele MJ. The first five years of universal hepatitis $B$ vaccination in South Africa: evidence for elimination of HBsAg carriage in under 5-year-olds. Vaccine. 2001;19(2829):3919-3926. doi:10.1016/s0264-410x(01)00120-7

29. Kidd-Ljunggren K, Myhre E, Bläckberg J. Clinical and serological variation between patients infected with different hepatitis B virus genotypes. J Clin Microbiol. 2004;42(12):5837-5841. doi:10.1128/jcm.42.12.58375841.2004

30. Xu Q, Shu X, Chen L, Zhou Y, Yao J. [Pathological changes between $\mathrm{HBeAg}$ and anti-HBe in patients with chronic hepatitis B]. Zhonghua Gan Zang Bing Za Zhi. 2001;9(6):340-342. 